\title{
Digestible arginine concentrations in the diet of Japanese quails
}

\section{Digestible arginine levels in diets for Japanese quails}

\author{
Thamírys Vianelli Maurício ${ }^{1 *}$; José Geraldo de Vargas Junior²; \\ Matheus Faria de Souza ${ }^{3}$; Walter Amaral Barboza ${ }^{2}$; Louisiane de Carvalho Nunes ${ }^{4}$; \\ Rita Trindade Ribeiro Nobre Soares ${ }^{4}$; Hugo da Silva Nascimento ${ }^{5}$
}

\begin{abstract}
The objective of this study was to evaluate the effect of different levels of arginine in the diet of Japanese quails and to determine which provides the best egg production indices. We used 400 birds with an initial average weight of $180 \mathrm{~g}$ at 140 days of age. These were distributed among experimental units in a randomized design. Five levels of digestible arginine were studied $(1.148,1.256,1.364,1.472$, and $1.580 \%)$ in reference to a fixed level of digestible lysine $(1.083 \%$; for arginine to lysine ratios of $1.06,1.16,1.26,1.36$, and 1.46). Each treatment was replicated 10 times for a total of 50 experimental units, each with eight quails. Feed rations, leftovers, and dead animals were weighed to calculate and adjust performance parameters. The variables analyzed were: daily feed intake (DFI), egg laying rate (ER), average egg weight (EW), total egg mass (EM), feed conversion per egg mass and per dozen eggs (FCEM and FCDE), yolk, skin, and albumen weights (AYW, ASW and AAW), relative weights of yolk, albumen and shell (RYW, RAW and RSW), the Haugh unit (HU), and the percentage of eggs suitable for market (EP). The variables associated with performance and internal and external quality were not affected $(\mathrm{P}>0.05)$ by different levels of arginine, except for $\mathrm{EP}$, which decreased linearly $(\mathrm{P}=0.009)$ with increasing arginine according to the equation: $\hat{Y}=-3.44 x+103.13, \mathrm{r}^{2}=0.94$. We conclude that the best concentration of arginine in quail diets is $1.148 \%$, corresponding to an arginine to lysine ratio of 1.06 .
\end{abstract}

Key words: Antagonism. Poultry. Amino acid imbalance.

\section{Resumo}

Objetivou-se avaliar o efeito de diferentes níveis de arginina digestível e determinar aquele que proporciona os melhores índices produtivos em dietas para codornas japonesas em postura. Foram utilizadas 400 aves com peso médio inicial de 180 gramas aos 140 dias de idade, distribuídas nas unidades experimentais em delineamento inteiramente casualizado. Foram utilizados cinco níveis crescentes de arginina digestível $(1,148 ; 1,256 ; 1,364 ; 1,472 ; 1,580 \%)$ sob um nível fixo de lisina digestível de $1,083 \%$, correspondendo à relação arginina: lisina digestível de $(1,06 ; 1,16 ; 1,26 ; 1,36 ; 1,46)$, portanto, foram cinco tratamentos com dez repetições cada, num total de 50 unidades experimentais. Cada unidade experimental continha oito codornas. As rações, as sobras e os animais mortos eram pesados a fim de se calcular e ajustar os parâmetros de desempenho. As variáveis analisadas foram: consumo de ração diário

\footnotetext{
${ }^{1}$ Mestre em Nutrição e Reprodução Animal, Universidade Federal do Espírito Santo, CCA/UFES, Alegre, ES, Brasil. E-mail: thavianelli@gmail.com

2 Profs. Drs., Departamento de Zootecnia, CCA/UFES, Alegre, ES, Brasil. E-mail: josegeraldovargas@yahoo.com.br; barbozawa@ hotmail.com

3 Dr. Nutrição de Monogástricos, Universidade Federal de Viçosa, UFV, Viçosa, MG, Brasil. E-mail: matheusfari@yahoo.com.br

${ }^{4}$ Prof $^{\text {as }}$ Dr $^{\text {a }}$, Departamento de Medicina Veterinária, CCA/UFES/ES; Dept ${ }^{\mathrm{o}}$ de Zootecnia, Universidade Estadual Norte Fluminense, UENF, Campos de Goytacazes, RJ, Brasil. E-mails: louisianecn@yahoo.com.br; rnobre@uenf.br

${ }^{5}$ Discente do Curso de Graduação em Zootecnia, CCA/UFES, Alegre, ES, Brasil. E-mail: hugonas@gmail.com

* Author for correspondence
} 
(CRD), taxa de postura (TP), peso médio dos ovos (PO), massa dos ovos (MO), conversão alimentar por massa de ovos e por dúzia de ovos (CAMO e CADO), pesos da gema, casca e albúmen (PG, PC e PA), pesos relativos da gema, da casca e do albúmen (PRG, PRC e PRA), além da unidade Haugh (UH) e percentual de ovos comercializáveis (OC). As variáveis de desempenho e de qualidade interna e externa de ovos em análise não foram afetadas $(\mathrm{P}>0,05)$ pelos diferentes níveis de arginina, a exceção do parâmetro ovos comercializáveis que decresceu linearmente $(\mathrm{P}=0,009)$ à medida que se aumentou $\mathrm{o}$ nível de arginina segundo a equação: $\hat{Y}=-3,44 x+103,13, r^{2}=0,94$. Conclui-se que o melhor nível de arginina para codornas em postura é de 1,148, cuja relação correspondente é a de 1,06 arginina:lisina.

Palavras-chave: Antagonismo. Aves. Desbalanço aminoacídico.

\section{Introduction}

Arginine is particularly important for birds, because unlike mammals, birds are unable to synthesize it in sufficient quantities to meet their physiological requirements. Furthermore, they do not use glutamic acid as a source of ornithine. Therefore, birds need to obtain arginine from their diet. The provision of dietary arginine should be sufficient to support protein synthesis, body growth, feather development, and other biological functions that depend on this amino acid (BALL et al., 2007).

Other than the tables proposed by Barral (1994), only two recent studies have evaluated the nutritional needs of quails: "Table for Japanese and European quails" by Silva and Costa (2009) and "Brazilian tables for poultry and swine" by Rostagno et al. (2011). In most poultry farms, maize and soybean meal are the primary ingredients of feed formulations. These meet most of the protein and energy requirements of poultry; however, they do not meet the need for certain essential amino acids. In general, it is a challenge for nutritionists to formulate diets that provide the correct amount of amino acids (JORDÃO FILHO et al., 2006).

The ideal protein concept has been used to justify decreasing the amount of crude protein (CP) in diets and to otherwise meet nutritional needs for essential amino acids through supplementation. Under this concept, lysine is used as the reference amino acid because of its importance in the nutrition of birds. Birds require lysine for protein synthesis and the biosynthesis of carnitine, an immunoregulator of the humoral response that increases blood levels of IgG.
However, excess intake of lysine can increase the need for arginine, resulting in arginine antagonism and thus impairing animal performance (HARPER et al., 1970).

This study therefore aimed to determine the nutritional needs of digestible arginine to maximize the production potential of Japanese quails.

\section{Materials and Methods}

The experiment was conducted in the poultry sector of the Federal Institute of Espírito Santo (Instituto Federal do Espírito Santo-IFES) in the city of Alegre (latitude $20^{\circ} 45^{\prime} 49^{\prime \prime}$, longitude $\left.41^{\circ} 31^{\prime} 57^{\prime \prime}\right)$ in the Rive district, state of Espírito Santo, Brazil. Alegre has an altitude of $150 \mathrm{~m}$, a tropical sub-humid climate, and a total annual rainfall of approximately $1200 \mathrm{~mm}$. An aviary was built with an east-west orientation, a ceiling height of $3.5 \mathrm{~m}$, an asbestos tile roof, and open, screened, and curtained sides. Egg quality was evaluated in the Laboratory of Bromatology and Animal Nutrition of the Department of Animal Sciences, located in the Agricultural Sciences Center of the Federal University of Espírito Santo (Centro de Ciências Agrárias da Universidade Federal do Espírito SantoCCA-UFES) in Alegre, Espírito Santo, Brazil.

The birds were housed in galvanized wire cages arranged in the form of ladders with three levels. These cages contained a front feeder, a nipple-type water dispenser on the opposite side, and an egg handling system. The dimensions of the cages were $1.00 \times 0.33 \times 0.15($ length $\times$ width $\times$ height $)$, and each unit was divided into 3 units of 0.33 meter in length. 
Four hundred female Japanese quails (Coturnix coturnix japonica) were used, each 140 days old and weighing 180 grams on average. These were distributed into 50 experimental units that were divided into 10 replicates of five treatments, with eight animals per experimental unit. The animals were given water and feed ad libitum during the experimental period. Feed was provided in two meals per day (the first at 08:00 $\mathrm{h}$ and the second at 17:00 h) to avoid waste. The experimental period lasted 84 days, divided into four periods of 21 days.

The quails were weighed before the experimental period and distributed according to weight intervals. Subsequently, egg production was monitored for 14 days. The animals were then redistributed according to their egg-laying capacity when the experimental period was initiated.

Diets based on corn and soybean meal were supplemented with L-arginine and L-lysine $\mathrm{HCl}$ to have five concentrations of digestible arginine $(1.148 \%, 1.256 \%, 1.364 \%, 1.472 \%$, and $1.580 \%)$ with a fixed concentration of digestible lysine $(1.083 \%)$, resulting in arginine:lysine ratios of 1.06 , $1.16,1.26,1.36$, and 1.46 , respectively, and a total of five treatments (Table 1).

Maximum and minimum temperatures and relative humidity in the aviary were measured daily and hourly during the experimental period using a data logger. The lighting period was based on a 16-h photoperiod. Natural light was supplemented with artificial light using an automatic control system.

The performance variables measured were egglaying rate (ELR; \%), average egg weight (AEW; g), total egg mass (EM; g/hen/day), daily feed intake (DFI; g/bird/day), feed conversion per egg mass (FCEM; g of ration/g of eggs), and feed conversion per dozen eggs (FCDE; g of ration/dozen eggs). Egg quality measures included absolute yolk weight (AYW; g), absolute shell weight (ASW; g), absolute albumen weight (AAW; g), relative yolk weight (RYW; \%), relative shell weight (RSW; $\%$ ), relative albumen weight (RAW; \%), the Haugh unit (HU), and the percentage of eggs suitable for market (EP; \%).

Eggs were collected daily at 08:00 $\mathrm{h}$ and production was expressed as percent per bird. To calculate EG, the production of eggs collected per bird per day was multiplied by AEW.

To determine the AEW, EM, FCEM, and egg quality measures (AYW, ASW, AAW, RYW, RSW, and RAW), five eggs were collected per day in each experimental unit during the last three days of the 2nd and 4th experimental periods, totaling 15 eggs per experimental unit per period evaluated. These samples were identified and weighed in the laboratory using a semi-analytical scale $( \pm 0.01$ $\mathrm{g})$. The height of the thick albumen was measured using a digital caliper coupled to a tripod.

After weighing, six eggs from the same experimental unit were separated. Three of these were used to determine the HU by breaking them on a flat surface, being careful to not break the internal egg structures, and measuring the height of the thick albumen. Subsequently, the three remaining eggs were also broken and the shell and yolk were separated.

The eggshells were washed, marked, dried in an oven at $65^{\circ} \mathrm{C}$ for 24 hours, and weighed. After washing and drying the eggs and weighing the whole eggs and egg yolks, the albumen weight was calculated by taking the difference between AEW and ASW.

To determine the $\mathrm{HU}$, the following equation was used: $\mathrm{HU}=100 \times \log \left(\mathrm{H}-1.7 \times \mathrm{W}^{0.37}+7.6\right)$. Where $\mathrm{H}$ is the height of the thick albumen and $\mathrm{W}$ is the weight of the whole egg (BAPTISTA, 2002).

DFI was calculated at the end of the experimental period by measuring the difference between the feed provided and what was left over. Dead birds and leftovers were weighed on the day of death to correct estimates of feed intake, egg-laying, and feed conversion (SAKOMURA; ROSTAGNO, 2007). 
Table 1. Composition of the diets.

\begin{tabular}{|c|c|c|c|c|c|}
\hline \multirow{2}{*}{$\begin{array}{l}\text { Ingredients (percent composition) } \\
\text { Concentration of digestible arginine }\end{array}$} & \multirow{2}{*}{1.148} & \multirow[b]{2}{*}{1.256} & \multirow[b]{2}{*}{1.364} & \multirow[b]{2}{*}{1.472} & \multirow[b]{2}{*}{1.580} \\
\hline & & & & & \\
\hline Corn & 57.879 & 55.112 & 54.988 & 55.085 & 54.962 \\
\hline Soybean meal 45 & 25.118 & 25.200 & 25.200 & 25.000 & 25.000 \\
\hline Limestone & 6.975 & 7.002 & 7.003 & 7.001 & 7.000 \\
\hline Meat and bone meal 44 & 4.135 & 4.038 & 4.039 & 4.046 & 4.047 \\
\hline Wheat bran & 0.930 & 3.000 & 3.000 & 3.000 & 3.000 \\
\hline Corn gluten meal 60 & 2.000 & 2.000 & 2.000 & 2.000 & 2.000 \\
\hline Soybean oil & 0.811 & 1.399 & 1.409 & 1.377 & 1.388 \\
\hline CL choline 60 & 1.000 & 1.000 & 1.000 & 1.000 & 1.000 \\
\hline Salt & 0.267 & 0.269 & 0.269 & 0.269 & 0.269 \\
\hline L-arginine & 0.000 & 0.099 & 0.209 & 0.324 & 0.433 \\
\hline DL-methionine & 0.365 & 0.364 & 0.364 & 0.366 & 0.366 \\
\hline L-lysine $\mathrm{HCl}$ & 0.297 & 0.290 & 0.291 & 0.297 & 0.297 \\
\hline L-tryptophan & 0.039 & 0.036 & 0.036 & 0.037 & 0.037 \\
\hline L-valine & 0.011 & 0.009 & 0.010 & 0.013 & 0.014 \\
\hline L-threonine & 0.013 & 0.013 & 0.013 & 0.016 & 0.016 \\
\hline Mineral supplementation for birds ${ }^{1}$ & 0.050 & 0.050 & 0.050 & 0.050 & 0.050 \\
\hline Mineral supplementation for birds ${ }^{2}$ & 0.100 & 0.100 & 0.100 & 0.100 & 0.100 \\
\hline Growth promoter ${ }^{3}$ & 0.010 & 0.010 & 0.010 & 0.010 & 0.010 \\
\hline Antioxidant ${ }^{4}$ & 0.010 & 0.010 & 0.010 & 0.010 & 0.010 \\
\hline Total & 100.000 & 100.000 & 100.000 & 100.000 & 100.000 \\
\hline \multicolumn{6}{|c|}{ Composition $(\mathrm{g} / \mathrm{kg})$} \\
\hline $\mathrm{ME}(\mathrm{Kcal} / \mathrm{kg})$ & 2.800 & 2.800 & 2.800 & 2.800 & 2.800 \\
\hline Crude protein & 200.220 & 201.100 & 201.020 & 200.350 & 200.270 \\
\hline Calcium & 30.990 & 30.990 & 30.990 & 30.990 & 30.990 \\
\hline Sodium & 1.550 & 1.550 & 1.550 & 1.550 & 1.550 \\
\hline Available phosphorus & 3.230 & 3.230 & 3.230 & 3.230 & 3.230 \\
\hline Linoleic acid & 18.130 & 21.040 & 21.080 & 20.910 & 20.940 \\
\hline Digestible arginine & 11.480 & 12.560 & 13.640 & 14.720 & 15.800 \\
\hline Digestible lysine & 10.830 & 10.830 & 10.830 & 10.830 & 10.830 \\
\hline Arginine:lysine ratio & 1.060 & 1.160 & 1.260 & 1.360 & 1.460 \\
\hline Digestive methionine + cysteine & 8.880 & 8.880 & 8.880 & 8.888 & 8.880 \\
\hline Digestible methionine & 6.290 & 6.270 & 6.280 & 6.290 & 6.290 \\
\hline Digestible tryptophan & 2.270 & 2.270 & 2.270 & 2.270 & 2.270 \\
\hline Digestible threonine & 6.490 & 6.490 & 6.490 & 6.490 & 6.490 \\
\hline Digestible valine & 8.120 & 8.120 & 8.120 & 8.120 & 8.120 \\
\hline Digestible isoleucine & 7.090 & 7.110 & 7.110 & 7.070 & 7.070 \\
\hline Digestible leucine & 16.150 & 16.060 & 16.050 & 15.990 & 15.980 \\
\hline Digestible phenylalanine & 8.670 & 8.680 & 8.680 & 8.640 & 8.640 \\
\hline Digestible phenylalanine + tyrosine & 14.870 & 14.880 & 14.880 & 14.810 & 14.800 \\
\hline
\end{tabular}

${ }^{1}$ Mineral supplement (per kg of product): $\mathrm{Cu}=6 \mathrm{~g} ; \mathrm{Fe}=30 \mathrm{~g} ; \mathrm{I}=400 \mathrm{mg} ; \mathrm{Mn}=50 \mathrm{~g} ; \mathrm{Se}=180 \mathrm{mg} ; \mathrm{Zn}=40 \mathrm{~g} .{ }^{2} \mathrm{Vitamin}$ supplement (per kg of product): Vitamin A = 12 million IU; Vitamin D3 = 2,000,000 IU; Vitamin K3 = 1,800 mg; Vitamin B1 = 1,500 mg; Vitamin B12 = $12.000 \mathrm{mcg}$; Vitamin B2 = $5.000 \mathrm{mg}$; Vitamin B6 = $2.800 \mathrm{mg}$; Vitamin E = 15,000 IU; Niacin = $35 \mathrm{~g}$; biotin = 25 $\mathrm{mg}$; pantothenic acid $=12 \mathrm{~g}$; folic acid $=750 \mathrm{mg}$. ${ }^{3}$ Zinc bacitracin. ${ }^{4}$ Butyl hydroxytoluene. 
Feed conversion was obtained by calculating the relationship between DFI and the average daily EP (conversion $\mathrm{g} / \mathrm{g}$ ) and the average daily production of a dozen eggs (conversion $\mathrm{kg}$ /dozen eggs). EP (\%) was calculated by dividing the number of intact eggs (without cracks, fractures, or soft shells) by the total number of eggs collected, multiplied by 100 .

The average values of performance and egg quality variables were analyzed by analysis of variance and polynomial regression using the System for Statistical Analyses and Genetics (UFV/SAEG, 2007) version 9.1 developed at the Federal University of Viçosa. For all statistical tests, p-values below 0.05 were considered significant.

\section{Results and Discussion}

Average values for temperature and relative humidity during the experimental period were 24.3 $\pm 5.6^{\circ} \mathrm{C}$ and $79.5 \pm 12.5 \%$, respectively. According to studies by Albino and Barreto (2003), Japanese quail in the egg-laying period have a thermal comfort interval between $19^{\circ} \mathrm{C}$ and $21^{\circ} \mathrm{C}$; however, these animals can still achieve high yields when kept at temperatures between $5^{\circ} \mathrm{C}$ and $30^{\circ} \mathrm{C}$. For relative humidity, comfort is closely associated with temperature. Previous studies have reported that a temperature of $32^{\circ} \mathrm{C}$ and a relative humidity of $50 \%$ demarcate the boundary for thermal comfort and approaching this interval can put the animals under heat stress (FERREIRA, 2005). We conclude that our experimental animals did not suffer heat stress.

DFI, ELR, AEW, EM, FCEM, and FCDE were not significantly affected by the different concentrations of arginine in the diet (Table 2).

Table 2. Performance variables of Japanese quails fed diets containing different arginine concentrations.

\begin{tabular}{lccccccc}
\hline \multirow{2}{*}{ Variables $^{2}$} & \multicolumn{9}{c}{ Arginine concentrations (\%) } & \multirow{2}{*}{ CV (\%) } & p-value $^{3}$ \\
\cline { 2 - 6 } & 1.148 & 1.256 & 1.364 & 1.472 & 1.580 & & \\
\hline DFI (g) & 26.31 & 26.42 & 27.02 & 25.57 & 26.63 & 10.32 & 0.866 \\
ELR (\%) & 93.63 & 92.90 & 91.20 & 91.66 & 91.62 & 4.03 & 0.823 \\
AEW (g) & 11.90 & 11.90 & 11.89 & 11.97 & 11.82 & 2.97 & 0.916 \\
EM (g) & 11.13 & 11.06 & 10.84 & 10.97 & 10.82 & 4.82 & 0.253 \\
FCEM (g/g) & 2.36 & 2.39 & 2.49 & 2.33 & 2.46 & 9.60 & 0.218 \\
FCDE (g/dozen eggs) & 0.34 & 0.34 & 0.35 & 0.33 & 0.35 & 10.01 & 0.985 \\
\hline
\end{tabular}

${ }^{1} \mathrm{CV}=$ coefficient of variation. ${ }^{2} \mathrm{DFI}=$ daily feed intake, $\mathrm{ELR}=$ egg-laying rate, $\mathrm{AEW}=$ average egg weight, $\mathrm{EM}=$ total egg mass, $\mathrm{FCEM}=$ feed conversion per egg mass, $\mathrm{FCDE}=$ feed conversion per dozen eggs. ${ }^{3}$ Values $>0.05$ were considered non-significant.

These results corroborate the findings of Santos (2013), who found no significant differences in the feed consumption of 147 day-old egg-laying Japanese quails provided different concentrations of arginine $(1.147 \%, 1.350 \%, 1.550 \%$, and $1.755 \%)$ in a diet with $16 \% \mathrm{CP}$. Similar results were obtained by Reis et al. (2012), who found no significant effect of different arginine:lysine ratios on feed intake by Japanese quails fed diets containing different concentrations of arginine.

We note that the diets used in this study were $20 \% \mathrm{CP}$, which is lower than the percentage recommended by Rostagno et al. (2011). Thus, all of the amino acids received by the animals were used in their entirety for maintenance and egg production. 
Previous studies (SCHUTTE; WEERDEN, 1987; WALDROUPE et al., 1976) indicated that if low-CP diets were supplemented with adequate amounts of essential and non-essential amino acids to meet the nutritional requirements of poultry, performance would be similar to that observed with conventional high-CP diets.

No significant effect $(\mathrm{P}>0.05)$ of different arginine concentrations was observed on the ELR. The average ELR found in this study was $91.90 \%$. The lack of an effect is consistent with the findings of Reis et al. (2012), who evaluated arginine concentrations in egg-laying Japanese quails.

In contrast, Ri et al. (2005) observed a decrease in the ELR in quails when fed diets with lower CP concentrations (16 to 26\%). Similarly, Lima and Silva (2007) evaluated different arginine:lysine ratios in feeds for light-weight and semi-heavy weight hens aged between 40 and 56 weeks and concluded that diets containing a ratio of 1.11 resulted in a higher EP than those with a ratio of 1.01 .

The differences between these studies may be due to different environmental conditions, amino acid concentrations, animal ages, or the species and animal lineages.

In the present study, there was no significant effect of arginine supplementation $(\mathrm{P}>0.05)$ on AEW. AEW was $11.90 \mathrm{~g}$, which is consistent with the results of Reis et al. (2012), who found no significant effect of different digestible arginine concentrations on the AEW of birds.

However, Lima and Silva (2007) evaluated laying hens and concluded that arginine concentrations of $0.72 \%$ and lysine concentrations of $0.71 \%$ resulted in higher AEW. This is similar to the results of Souza (2009), who evaluated arginine:lysine ratios of 0.9:1.0, 1.0:1.0, and 1.1:1.0 for laying hens and found a linear positive effect on the AEW as the ratio increased from $0.9: 1.0$ to 1.1:1.0.

Murakami and Ariki (1998) measured an AEW of $10.39 \mathrm{~g}$ for eggs produced between the 36th and 44 th week of production. The AEW values obtained in our study were higher than those obtained by these authors, and much higher than the values of $10.11 \mathrm{~g}$ and $10 \mathrm{~g}$ found by Santos (2013) and Albino and Barreto (2003), respectively.

AEW is strongly dependent on protein intake because birds depend on their daily intake of arginine to meet their energy demands. Although quail eggs are usually sold per unit and not by weight, the use of low-protein concentrations without amino acid supplementation may compromise egg size, making them non-standard. Of note, this problem did not occur in this study with a CP concentration of $20 \%$, which is lower than that suggested by Rostagno et al. (2011), but is in accordance with the recommendations of Silva and Costa (2009).

In addition, in this study we used birds in the intermediate stage of life, and this may have been a factor contributing to the high AEW we observed. Britton (1976) associated the decline in the internal and external quality of eggs to the aging of the birds and reported a significant increase in the AEW of birds at the end of their egg-laying period.

EM averaged $10.10 \mathrm{~g}$ and was not affected $(\mathrm{P}>$ 0.05 ) by the different arginine concentrations in the diet. These results corroborate those found by Santos (2013), who used a total arginine concentration between $0.945 \%$ and $1.755 \%$ with 147-day-old quails and found no effect of supplementation on EM. Similarly, Reis et al. (2012) found no effect of arginine:lysine ratios on EM when studying Japanese quail hens. By contrast, Souza (2009) observed a positive linear response of EM as the arginine:lysine ratio increased from 0.9 to $1.1: 1.0$

The EM measured in this study was higher than that found by Murakami and Ariki (1998), who estimated an EM of 8.29 for quails reared between the 36th and 44th weeks of production. Taking into account that EM involves the egg-laying rate and egg weight and that these characteristics were not affected in this study, no effect of arginine 
concentration on EM was expected. According to Llobet et al. (2010), EM is a useful parameter for evaluating the performance of a large number of laying birds; therefore, the average EM found in this study indicates that our birds exhibited remarkable performance.

The supplementations performed in the present study did not affect DFI, ELR, or EM (P > 0.05). As such, the lack of differences in the derived variables, FCEM and FCDE, were expected ( $\mathrm{P}>$ $0.05)$.

Our results agree with those found by Santos (2013), who evaluated 147-day-old Japanese quails with diets containing $0.945-1.755 \%$ arginine and $16 \% \mathrm{CP}$. They observed that FCEM and FCDE were not significantly affected by arginine concentrations. Reis et al. (2012) and Souza (2009) found similar results using different digestible arginine concentrations.

In contrast, Lima and Silva (2007) found the highest FCEM using the lowest lysine concentration $(0.71 \%)$ and the highest arginine concentration $(0.79 \%)$ or using an arginine:lysine ratio of 1.11 with two concentrations of lysine $(0.71,0.78)$ and three concentrations of arginine $(0.64,0.72$, and $0.79)$.

No significant effects $(\mathrm{P}>0.05)$ of digestible arginine concentrations were observed on YW, SW, AW, RYW, RSW, RAW, or UH. On the other hand, there was a decreasing linear effect on EP (P $=0.009$ ) according to the equation: $\hat{\mathrm{Y}}=-3.44 \mathrm{x}+$ 103.13, $\mathrm{r}^{2}=0.94$ (Table 3).

Table 3. Quality measures of eggs from quails fed diets with different arginine concentrations.

\begin{tabular}{lccccccc}
\hline \multirow{2}{*}{ Quality measures $^{2}$} & \multicolumn{9}{c}{ Arginine concentrations (\%) } & \multirow{2}{*}{ CV (\%) } & p-value $^{4}$ \\
\cline { 2 - 6 } & 1.148 & 1.256 & 1.364 & 1.472 & 1.580 & & \\
\hline YW (g) & 3.89 & 3.99 & 3.92 & 3.94 & 4.01 & 4.48 & 0.269 \\
SW (g) & 0.91 & 0.96 & 0.94 & 0.96 & 0.93 & 11.53 & 0.876 \\
AW (g) & 7.09 & 6.95 & 7.02 & 7.07 & 6.86 & 3.79 & 0.871 \\
RSW (\%) & 7.89 & 7.97 & 7.33 & 8.03 & 7.40 & 10.26 & 0.273 \\
RAW (\%) & 61.57 & 60.29 & 60.34 & 59.07 & 60.11 & 6.72 & 0.841 \\
RYW (\%) & 32.71 & 33.52 & 32.99 & 32.94 & 33.97 & 3.57 & 0.835 \\
HU & 78.19 & 78.14 & 78.16 & 78.03 & 78.02 & 0.69 & 0.931 \\
EP (\%) & 99.08 & 98.86 & 98.64 & 97.90 & 97.70 & 1.39 & 0.009 \\
\hline
\end{tabular}

${ }^{1}$ Decreasing linear effect $(\mathrm{p}=0.009)$, equation $\hat{\mathrm{Y}}=-3,44 \mathrm{x}+103.13, \mathrm{r}^{2}=0.94 .{ }^{2} \mathrm{YW}=$ yolk weight, $\mathrm{SW}=$ shell weight, AW $=$ albumen weight, RSW = relative shell weight, RAW = relative albumen weight, RYW = relative yolk weight, HU = Haugh unit, EP $=$ egg production. ${ }^{3} \mathrm{CV}=$ coefficient of variation. ${ }^{4}$ Values $>0.05$ were considered non-significant.

Similar results were obtained by Santos (2013) and Reis et al. (2012), who found no significant effect of dietary arginine concentrations $(0.945 \%$ to $1.755 \%$ and $1.16 \%$ to $1.36 \%$, respectively) on the internal or external quality of Japanese quail eggs.

There was no effect $(\mathrm{P}>0.05)$ of different dietary arginine concentrations on RAW, RYW, and RSW. Our results were similar to those of Santos (2013) using different arginine concentrations. However, these authors found a positive correlation with RSW. Souza (2009) evaluated arginine:lysine ratios between $0.9 \%$ and $1.1 \%$ in the diets of laying hens and found no significant difference in RSW.

Given that the solid component of the egg albumen is almost entirely protein, a hen's demand for protein and amino acids is large. In other words, protein deficiencies could cause a decrease in the amount of albumen and in egg size, and 
consequently, in the amount of yolk. However, none of these outcomes occurred in this study. This suggests that the lowest concentration of arginine used $(1.148 \%)$ was sufficient for maintaining good internal egg quality.

There was no significant effect $(\mathrm{P}>0.05)$ of arginine concentration on $\mathrm{HU}$. According to Alleoni and Antunes (2001), HU is a measure most commonly used to express albumen quality. Egg quality varies with the logarithm of the height of the thick albumen, and the higher the HU, the higher the internal quality of the egg. The internal quality of eggs can be influenced by numerous factors, including biological characteristics (age and genetics), nutrition (raw materials and micronutrients), and the environment (temperature, storage, and management of the eggs) (LEANDRO et al., 2006). The average HU found in the present study was most likely a product of the age our animals, because advancing age leads to a gradual decrease in internal egg quality (CARVALHO et al., 2007). Other factors, such as the high temperatures and humidity inside the aviary or the amount of $\mathrm{CP}$ in the diet (which may have been too low to achieve adequate albumen density), could also explain the moderate HU values observed. Our results contrast with those of Santos (2013) and Reis et al. (2012), who evaluated Japanese quails fed diets supplemented with arginine and found no significant effect on egg quality.

The bird age, aviary temperature, cage structure, cage materials, and egg collection frequency are all factors that can decrease egg production (HAMILTON, 1982).

Although no significant effects of digestible arginine concentration were observed on other production parameters, the increase in the arginine:lysine ratio did have a linear effect on the percentage of eggs found suitable for market.

\section{Conclusion}

The concentration of digestible arginine that produced the best production yield was $1.148 \%$, corresponding to an arginine:lysine ratio of 1.06:1.00.

\section{References}

ALBINO, L. F. T.; BARRETO, S. L. T. Codornas. Criação de codornas para produção de ovos e carne. Viçosa, MG: Aprenda Fácil, 2003. 289 p.

ALLEONI, A. C. C.; ANTUNES, A. J. Unidade Haugh como medida da qualidade de ovos de galinha armazenados sob refrigeração. Scientia Agrícola, Piracicaba, v. 58, n. 4, p. 681-685, 2001.

BALL, R. O.; URSCHEL, K. L.; PENCHARZ, P. B. Nutritional consequences of interspecies differences in arginine and lysine metabolism. The Journal of Nutrition, Toronto, v. 137, n. 6, p. 1626S-1641S, 2007.

BAPTISTA, R. F. Avaliação da qualidade interna de ovos de codorna (Coturnix coturnix japônica) em função da variação da temperatura de armazenamento. 2002. Dissertação (Mestrado em Medicina Veterinária) Universidade Federal Fluminense, Niterói.

BARRAL, A. D. Manual de la Codorniz: cria industrial y para la caza. Lleida: Dilagro, 1994. 268 p.

BRITTON, W. M. Effect of albumen $\mathrm{pH}$ on yolk mottling. Poultry Science, Champaign, v. 55, n. 4, p. 1330-1335, 1976.

CARVALHO, F. B.; STRINGHINI, J. H.; JARDIM FILHO, R. M. de; LEANDRO, N. S. M.; CAFÉ, M. B.; DEUS, H. A. S. B. de. Qualidade interna e da casca para ovos de poedeiras comerciais de diferentes linhagens e idades. Ciência Animal Brasileira, Goiânia, v. 8, n. 1, p. 25-30, 2007.

FERREIRA, R. A. Maior produção com melhor ambiente para aves, suínos e bovinos. Viçosa, MG: Aprenda Fácil, 2005. $371 \mathrm{p}$.

HAMILTON, R. M. G. Methods and factors that affect the measurement of egg shell quality. Poultry Science, Champaign, v. 61, n. 6, p. 2022-2039, 1982.

HARPER, A. E.; BENEVENGA, N. J.; WOHLHUETER, R. M. Effects of ingestion of disproportionate amounts of amino acids. Physiological Reviews, Bethesda, v. 50, n. 4, p. 428-547, 1970. 
JORDÃO FILHO, J.; SILVA, J. H. V.; SILVA, E. L. Exigência de lisina para poedeiras semipesadas durante $\mathrm{o}$ pico de postura. Revista Brasileira de Zootecnia, Viçosa, MG, v. 35, n. 4, p. 1728-1734, 2006.

LEANDRO, N. S. M.; DEUS, H. A. B. de; STRINGHINI, J. H.; CAFÉ, M. B.; ANDRADE, M. A.; CARVALHO, F. B. de. Aspectos de qualidade interna e externa de ovos comercializados em diferentes estabelecimentos na região de Goiânia. Ciência Animal Brasileira, Goiânia, v. 6, n. 2, p. 71-78, 2006.

LIMA, M. R.; SILVA, J. H. V. Efeito da relação lisina: arginina digestível sobre o desempenho de poedeiras comerciais no período de postura. Revista Acta Veterinária Brasilica, Mossoró, v. 1, n. 4, p. 118-124, 2007.

LlOBET, J. A. C. Producción de huevos: con la participación de 14 autores. Barcelona: Real Escuela de Avicultura, 2010.

MURAKAMI, A. E.; ARIKI, J. Produção de codornas japonesas. São Paulo: Editora Funep, 1998. 79 p.

REIS, R. S.; BARRETO, S. L. D. T.; ABJAUDE, W. D. S.; DUTRA, D. R.; SANTOS, M.; PAULA, E. D. Relationship of arginine with lysine in diets for laying Japanese quails. Revista Brasileira de Zootecnia, Viçosa, MG, v. 41, n. 1, p. 106-110, 2012.

RI, E.; SATO, K.; OIKAWA, T.; KUNIEDA, T.; UCHIDA, H. Effects of dietary protein levels on production and characteristics of Japanese quail eggs. The Journal of Poultry Science, Tsukuba, v. 42, n. 2, p. 130-139, 2005.
ROSTAGNO, H. S.; GOMES, P. C.; OLIVEIRA, R. F.; LOPES, D. C.; FERREIRA, A. S.; BARRETO, S. L. T.; EUCLIDES, R. F. Tabelas brasileiras para aves e suinos: composição de alimentos e exigências nutricionais. 3. ed. Viçosa, MG: Universidade Federal de Viçosa, 2011. 259 p.

SAKOMURA, N. K.; ROSTAGNO, H. S. Métodos de pesquisa em nutrição de monogástricos. Jaboticabal: Funep, 2007. 283 p.

SANTOS, G. C. Niveis de valina, isoleucina e arginina em dietas com baixo nível proteico para codornas japonesas em postura. 2013. Tese (Doutorado em Zootecnia) - Universidade de São Paulo, São Paulo.

SCHUTTE, J. B.; WEERDEN, E. J. Effectiveness of methionine hydroxyl analogue as affected by the dietary level of L-methionine in chicks. Nutrition Report International, v. 36, n. 2, p. 253-259, 1987.

SILVA, J. H. V.; COSTA, F. G. P. Tabela para codornas japonesas e européias. 2. ed. Jaboticabal: FUNEP, 2009, $110 \mathrm{p}$.

SOUZA, H. R. B. D. Formulação de dietas com aminoácidos totais e digestíveis, diferentes relações arginina: lisina e fontes de metionina para poedeiras comerciais. 2009. Tese (Doutorado em Zootecnia) Universidade de São Paulo, São Paulo.

UNIVERSIDADE FEDERAL DE VIÇOSA - UFV. SAEG - Sistema para análise estatística e genética. Versão 9.1.Viçosa, MG: Fundação Arthur Bernardes, 2007. CD-ROM.

WALDROUP, P. W.; HAZEN, K. R.; BUSSELL, W. D.; JOHNSON, Z. B. Studies on the daily protein and amino acid needs of broiler breeder hens. Poultry Science, Champaign, v. 55, n. 6, p. 2342-2347, 1976. 
